\title{
Testemunhos 'geo-mineralógicos' do Império Português no Oriente nas coleções do Museu Nacional de História Natural e da Ciência (Lisboa, Portugal) \\ Geological testimonies of the Portuguese Empire in the East among the collections of the Museu Nacional de História Natural e da Ciência (Lisbon, Portugal)
}

\author{
José Manuel Brandão \\ Universidade de Évora. Évora, Portugal
}

\begin{abstract}
Resumo: O Museu Mineralógico e Geológico da Faculdade de Ciências de Lisboa conservou, até o incêndio de 1978, amostras representativas de diversas unidades geológicas de Timor, coletadas de forma voluntariosa por agentes da administração colonial. $\bigcirc$ estudo deste acervo, que durante muitos anos foi o único do gênero em museus da metrópole, ajudou a fazer luz sobre a geologia da mais longínqua parcela do Império Colonial Português, apresentada, em traços gerais, ao Congresso Geológico Internacional, reunido em Londres em 1948. A maior parte destas amostras perdeu-se em 1978, conservando-se, contudo, as coleções que foram recolhidas a mando do governador da província, por solicitação do autor da comunicação àquele congresso, antigo naturalista do museu. No presente artigo, alicerçado no estudo da sua documentação científica, revisita-se o conjunto do acervo para esboçar o seu contexto de formação e a composição, destacando-o enquanto marco da soberania e de afirmação da ciência colonial no oriente português.
\end{abstract}

Palavras-chave: Timor. Coleções geológicas. Museu Mineralógico e Geológico. Ciência colonial.

\begin{abstract}
The Mineralogical and Geological Museum of the Faculty of Sciences in Lisbon preserved until the fire of 1978 samples representing several geological units of Timor, collected willfully by agents of the colonial administration. The study of this unique collection in the mainland museums has helped to shed light on the geology of the most distant overseas Portuguese territory. The results were presented at the International Geological Congress, held in London in 1948. Most of the samples were lost in 1978, saving up however the collections sent by the governor of the province to the author of the study on the geology of Timor, former naturalist of the museum. This paper is based on scientific documentation and revisits the collections in order to contextualize its formation and composition, highlighting its role as landmark of sovereignty and the assertion of colonial science in the Portuguese Empire of the East.
\end{abstract}

Keywords: Timor. Geological collections. Mineralogical and Geological Museum. Colonial science.

BRANDÃO, José Manuel. Testemunhos 'geo-mineralógicos' do Império Português no Oriente nas coleções do Museu Nacional de História Natural e da Ciência (Lisboa, Portugal). Boletim do Museu Paraense Emílio Goeldi. Ciências Humanas, v. 8, n. 2, p. 401-418, maio-ago. 2013.

Autor para correspondência: José Manuel Brandão. Centro de Estudos de História e Filosofia da Ciência. Universidade de Évora. Palácio do Vimioso, Largo Marquês de Marialva, 8. 7000-554. Évora, Portugal (josembrandao@gmail.com).

Nota do Editor: a grafia de algumas palavras e a sintaxe do original foram adequadas ao português falado no Brasil.

Recebido em 04/05/2012

Aprovado em 25/06/2013

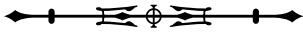




\section{INTRODUÇÃO}

Timor foi, ao menos desde o segundo quartel do século XIX, um ponto de convergência de técnicos internacionais em razão da ocorrência de petróleo e de outras substâncias minerais com importância econômica, e da diversidade da fauna fóssil permocarbônica, interesse acrescido mais recentemente pelo estudo do seu enquadramento geotectônico no Arco de Banda, estrutura complexa gerada pela interação das placas Eurásia, Austrália e Pacífica (Ribeiro e Leme, 2010). No seu conjunto, todos esses trabalhos permitem hoje um conhecimento geral da geologia e dos recursos minerais da região.

No lado português da ilha, atual República do TimorLeste, apesar de cedo se ter reconhecido a premência de um levantamento geológico geral, ferramenta essencial do 'fomento colonial', foram bem modestas as contribuições, o que se explica, por um lado, pela enorme distância que separava Timor da metrópole, responsável por décadas de desinteresse pela ilha; por outro, pela maior atração exercida pelas antigas colônias africanas, encaradas, desde o segundo quartel do século XIX, como 'novos Brasis'. Não se pode, contudo, negligenciar algumas tentativas de reconhecimento das potencialidades minerais do subsolo timorense, promovidas pelo governo central ou por iniciativa de agentes da administração colonial, traduzidas na coleta de amostras enviadas para Lisboa, parte das quais veio a ser depositada no Museu Mineralógico e Geológico da Faculdade de Ciências de Lisboa, atualmente integrado ao Museu Nacional de História Natural e da Ciência da Universidade de Lisboa (MUHNAC).

De Timor, ainda se conserva uma pequena parcela da coleção ali depositada em 1917, a qual escapou ao incêndio de março de 1978 - responsável pela destruição da maior parte do edifício da Faculdade, ocasionando irreparáveis perdas do acervo -, bem como parte das amostras que, ao final dos anos 1940, tinham sido confiadas para estudo ao antigo naturalista do museu, António da Silva e Sousa Torres (1876-1958)', e ainda se mantinham na morada da família, onde ele continuara a trabalhar após a aposentadoria.

O espólio científico deste naturalista, doado ao museu pelos familiares, em finais dos anos 1980, permite recuperar a memória e revisitar os primeiros passos da investigação geológica da mais longínqua parcela do Império Colonial Português no Oriente. Esta documentação, na qual se alicerça a presente contribuição, é, pois, peça fundamental não apenas para o estudo e a compreensão das dinâmicas do museu, como também para o estudo da história das geociências no Portugal metropolitano e ultramarino.

\section{DAS PESQUISAS DE PETRÓLEO À CARTA GEOLÓGICA}

A notícia da ocorrência de substâncias betuminosas em Timor, há muito aproveitadas pelos naturais, motivou, desde a segunda metade de oitocentos, a realização de diversos estudos geognósticos ou naturalísticos, em sua maioria realizados por geólogos suíços, alemães e holandeses. Tais estudos, que incidiram em particular sobre a metade holandesa da ilha, demonstraram que Timor não era uma ilha vulcânica, como até então se admitira por analogia com outras ilhas do IndoPacífico, evidenciando, pelo contrário, abundância de rochas sedimentares e metamórficas, e faunas fósseis diversificadas, repartidas pelas diversas divisões do calendário geológico. Tema fulcral de observação do alemão Johann Wanner (1878-1959) a partir de 1906, os fósseis foram objeto de importantes estudos de detalhe, publicados a partir de 1914 (Wanner, 1914-1929).

$\mathrm{Na}$ metade portuguesa da ilha (Figura 1), surgiram também alguns trabalhos monográficos assinados por autores nacionais, onde se referem sumariamente os

\footnotetext{
1 Bacharel em Filosofia Natural pela Universidade de Coimbra, foi nomeado como naturalista do Museu Mineralógico e Geológico da Faculdade de Ciências em 1919. Foi responsável pela reclassificação e rearranjo das coleções de estratigrafia e paleontologia, imprimindolhes a organização que perdurou até o incêndio de 1978 (Brandão, 2011, p. 1136).
}

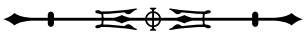




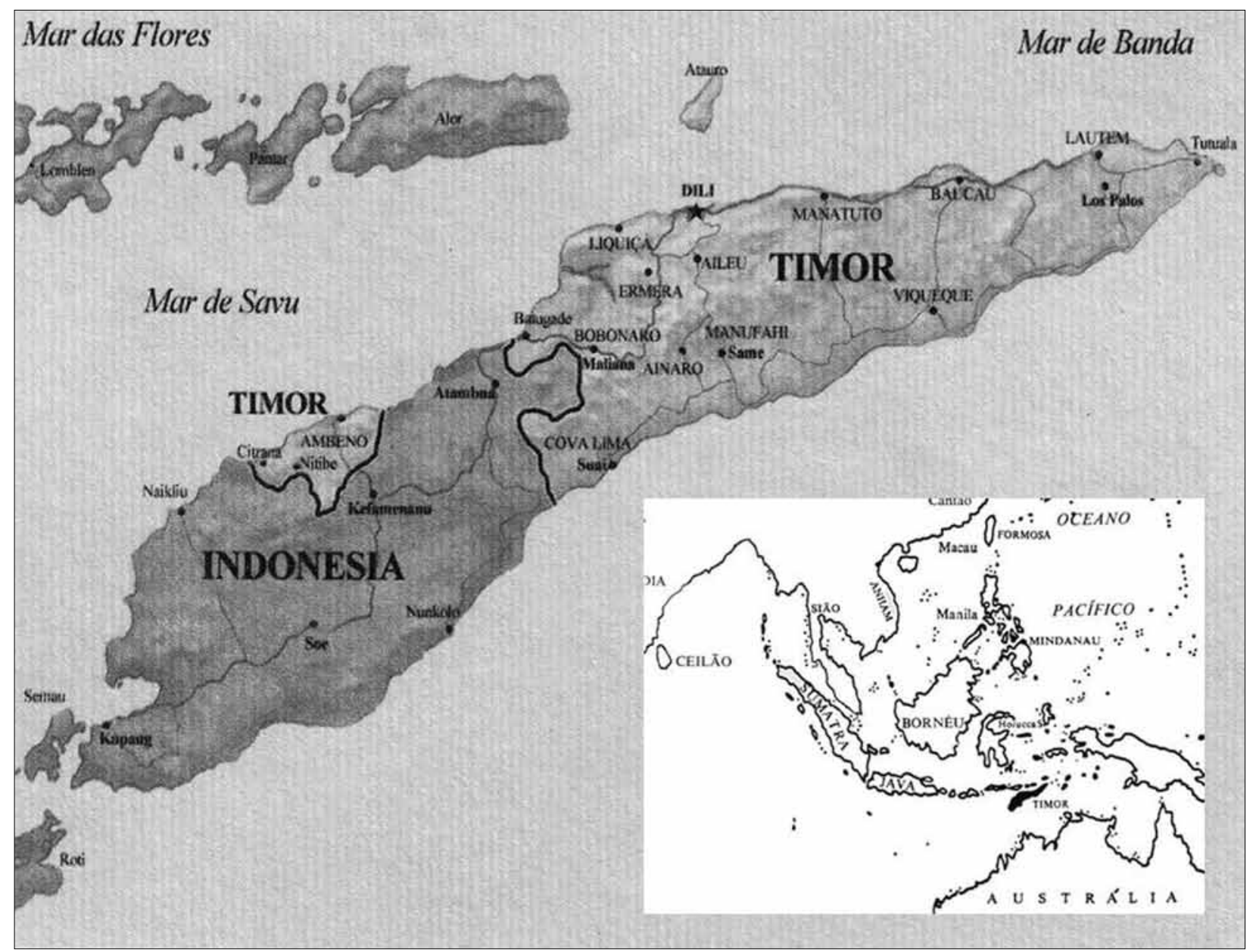

Figura 1. Timor, esboço geográfico. Adaptado de Carvalho, 2003.

principais traços da geologia e os principais recursos minerais. Neste âmbito, a generalidade das referências apontava particularmente para a ocorrência de cobre nativo no reino ${ }^{2}$ de Vemasse (Castro, 1867, p. 302), e de metais preciosos no reino de Turiscai, em Bibiçuço e Tara-Dai, de onde saíra o ouro usado para pagar as fintas 3 à Fazenda Pública (Vaquinhas, 1882a, p. 41). Nesses trabalhos, são ainda referidas exsudações de naftas e emanações de gases combustíveis, de há muito aproveitadas pelos naturais, e de petróleo que "escorria a jorros" de nascentes na periferia dos vulcões de lama de Bibiluto e Laclubar (Vaquinhas, 1882b, p. 242).

Estas ocorrências despertaram a atenção do general Celestino da Silva (1849-1911), governador de Timor entre 1894 e 1908, que impulsionou os trabalhos de pesquisa de petróleo, chamando a atenção do poder central para a importância deste recurso, que, em sua opinião, poderia vir a colmatar definitivamente a crônica situação de deficit financeiro do território. Foi graças a este impulso que se levaram a cabo os primeiros estudos

\footnotetext{
2 Na segunda metade do século XIX, Timor português encontrava-se retalhado em pequenos territórios relativamente autônomos, os 'reinos', abrangendo diversos sucos, povoações ou aldeias, governados por chefes, os liurais, que o governo colonial reconhecia como reis. 3 Impostos em gêneros cobrados pelo governo.
}

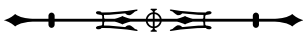


detalhados sobre a geologia de Timor português pelo suíço Hans Hirschi, que empreendeu, em 1904, um rápido reconhecimento da região entre Manatuto e a costa sul para avaliação do potencial petrolífero (Teixeira, 1952, p. 67; Audley-Charles, 1968, p. 1):

Eu nada entendo de exploração de petróleo, nem posso calcular senão pelo que tenho ouvido aos representantes dos sindicatos que têm visitado o jazigo de Laclubar, e que é de supor ocultem cuidadosamente o seu verdadeiro juízo, o que ele pode produzir, mas é me licito julgar, pelo fato da concessão ser almejada e questionada, que tal jazigo tem verdadeiro valor, e lógico é concluir que a receita para esta colônia irá além do que no contrato de concessão for estabelecido, porque a exploração terá como lógicas consequências a concorrência do pessoal, e o aumento de consumo, que exercerá bem firme influência nas cobranças realizadas pela alfândega (DirecçãoGeral do Ultramar, 1906, p. 14).

Em 1906, na sequência das diligências de Celestino da Silva, o governo de Lisboa incumbiu o general José Emílio Castel Branco (18--?-1961), que à altura prestava serviço em Macau, de se deslocar a Timor para avaliar e reportar a riqueza petrolífera do território. Acompanhado pelo tenente da Armada Júlio Montalvão e Silva (1873-1950), percorreu as regiões onde havia notícia das ocorrências, colhendo amostras de rochas e de óleos minerais em Pualaca, Vessoro, Alas e Vemasse (Castel Branco, 1915, p. 67). Os petróleos foram enviados para análise a (Sir) Boverton Redwood (1846-1919), reputado consultor inglês, secretário da Petroleum Association britânica, e ao químico industrial australiano James Elliot (1858-1928), que visitara Timor. As rochas foram remetidas para Lisboa, desconhecendose o seu paradeiro atual.

O relatório enviado pelo militar à Direção-Geral do Ultramar denota, de forma evidente, a manifesta falta de conhecimento que se tinha da geologia da província, bem como a urgência de promover esse estudo:

É (...) fora de dúvida ser de grande importância e de urgência o proceder-se não só ao reconhecimento geológico especialmente aplicável às investigações sobre os jazigos de petróleo em Timor, mas também ao reconhecimento geral geológico e petrográfico ou mineralógico d'esta província que, além do petróleo e segundo informações de diversas origens, contêm minérios de cobre, arsênico, ouro, fosfatos alcalinos, sal-gema, amianto e grande variedade de pirites (Castel Branco, 1915, p. 48).

Concentrado em outras tarefas da colonização, o governo provincial pouco ou nada fez neste capítulo, além de seguir de longe os trabalhos das companhias petrolíferas, que gradualmente se foram desinteressando, como reportou Teófilo Duarte (1898-1958), governador de Timor entre 1926 e 1928:

Entre as indústrias timorenses suscetíveis de serem desenvolvidas (...) figura o petróleo cujas repetidas e constantes pesquisas, algumas vezes com sucesso relativo, permitem alimentar a esperança de que um dia ele possa vir a constituir uma fonte importante de rendimentos da Colônia. Na Aliambata, Pualaca e Suai ${ }^{4}$ há vestígios da sua existência comprovada pelo uso imemorial que o indígena dele faz e ainda noutros pontos aparecem asfaltos e óleos hidrocarbonados, que tanto podem ser indicação da existência de importantes quantidades nas regiões profundas como restos de jazigos que (...) se tem ido esgotando para o mar. Os trabalhos de exploração têm porém estado a cargo de entidades que, ou pelos seus fracos recursos, ou devido a intuitos reservados, nada de concreto fazem, limitando as suas pesquisas a um ou outro poço que nunca vai além de 800 pés (Duarte, 1930, p. 173).

Contudo, os trabalhos de reconhecimento não estiveram completamente parados, destacando-se, em meados de 1920, os levantamentos do geólogo americano Stuart St. Clair e colaboradores, compulsados em um

\footnotetext{
${ }^{4} \mathrm{Na}$ Exposição Colonial de Timor, organizada na Sociedade de Geografia em 1931, estiveram patentes amostras de petróleos refinados da mina de Hera no Suai, da ribeira de Pualaca e de Laclubar, juntamente com outras substâncias de origem mineral (Lencastre, 1931).
}

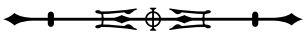


relatório ilustrado com mapas e cortes, que forneceram, como afirma Hans Grunau (1957, p. 757), "a primeira síntese geológica global da região". Seguiram-se-lhe os reconhecimentos dos recursos mineiros e petrolíferos da Allied Mining Company, coordenados pelo engenheiro belga Serge Wittouck, desembarcado na ilha com "uma verdadeira missão de geólogos, topógrafos e técnicos de outras especialidades" ${ }^{\text {. }}$. Publicados em 1937 sob a forma de um relatório muito completo, acompanhado de um esboço geológico na escala 1:500.000, constituíram um dos mais importantes trabalhos da primeira metade do passado século (Wittouck, 1937).

A despeito das tentativas de garantir o monopólio da pesquisa de petróleo para a companhia japonesa Asia Investment Company, que, sob a direção de Wittouck, sucedera à Allied, outras companhias tentaram estabelecer-se também em Timor oriental para fazer prospeção. Citem-se, por exemplo, a americana Super Oil; a Oil Search Limited, estabelecida nas Índias Orientais Holandesas; e a recémformada portuguesa Companhia Ultramarina de Petróleos, à qual fora atribuída, por contrato de novembro de 1939, a concessão da pesquisa de petróleos na metade oriental do Timor português (Carvalho, 2003, p. 59; Leme, 1968, p. 111).

Os trabalhos da companhia portuguesa ganharam fôlego a partir de abril de 1941, quando chegaram a Timor o engenheiro Veiga Lima, administrador, e o geólogo holandês Émile Brower, que vinham dar início ao programa exposto ao governador e que havia sido aprovado pelo Ministério das Colônias, cujo começo seria dado com o levantamento fotogramétrico das áreas potencialmente mais interessantes, estudos geológicos e sondagens. Para estes trabalhos, dada a natureza e o denso clima político, foi solicitado o acompanhamento pessoal do coronel Jorge Castilho (1880-1943), à época o oficial português mais graduado em território timorense e que chefiava a Missão Geográfica ali instalada 6 . De acordo com Carvalho (2003, p. 61), "o sr. coronel Jorge Castilho anuiu imediatamente a tomar esse encargo, prestando assim ao governo da colônia uma boa colaboração, tendo-lhe sido dada a maior latitude quanto à forma de exercer essa fiscalização e a sua amplitude". A Companhia Ultramarina de Petróleos veria, entretanto, reforçados os seus quadros técnicos com a chegada do topógrafo suíço Ernest Keller e do geólogo inglês W. Johnstone.

Suspensos após a invasão japonesa da Segunda Guerra Mundial, os trabalhos de pesquisa voltaram a intensificar-se na segunda metade da década de quarenta, com os estudos dos suíços Hans Grunau e F. Escher, que, entre 1947 e 1948, percorreram Timor trabalhando para a Royal Dutch Shell (Audley-Charles, 1968, p. 2) e, depois de 1955, com os trabalhos de Robert Gageonnet e Marcel Lemoine (19242009), por conta do governo português. Estes trabalhos completaram-se com as leituras globais do geólogo inglês Michael Audley-Charles (n. 1935), gizadas na estada em Timor Leste entre 1959 e 1962, a serviço de uma petrolifera, publicando sistematicamente, desde então, sobre a geologia timorense, de que se destaca, daquele período, a memória de 1968, acompanhada de uma carta na escala 1:250.000.

Acresce dizer que, não obstante o conhecimento de diversas exsudações, concentradas, sobretudo, na metade oriental da ilha, sempre se colocaram sérias dificuldades à localização, compreensão e avaliação do potencial dos jazigos de petróleo, decorrentes da complexa estrutura tectônica de Timor, marcada por grandes carreamentos e dobramentos (Leme, 1968, p. 153).

Finalmente, durante a década de 1960, no quadro das Missões Agronômicas criadas pela extinta Junta das Missões Geográficas e de Investigações Coloniais, o governo português promoveu a realização dos levantamentos para a elaboração da Carta dos Solos

\footnotetext{
5 Entrevista ao coronel Álvaro de Fontoura. Diário Popular, Edição especial dedicada ao Ultramar Português, Lisboa, p. 22-23, 20 out. 1951. Arquivo Histórico do Museu Nacional de História Natural e da Ciência (doravante, AH-MUHNAC), Lisboa, Portugal.

6 Criada por diploma em 16 de outubro de 1937, a Missão Geográfica de Timor tinha por objetivo realizar a geografia geral da colônia e, em especial, os estudos geodésicos, geológicos e cartográficos.
}

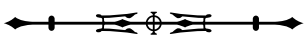


de Timor, deslocando para o território uma equipe constituída por agrônomos e regentes agrícolas, integrando dois geólogos, Azeredo Leme e J. Bailim Pissara, autores de vários trabalhos de síntese (ver, por exemplo, Leme, 1968) e levantamentos de pormenor, cuja contribuição foi decisiva para a conclusão da atual carta geológica da antiga colônia portuguesa.

\section{AGRIMENSURA, CURIOSIDADE E GEOLOGIA: DE MÃOS DADAS}

Em fevereiro de 1913, embarcou em Lisboa, com destino a Timor, o tenente de engenharia Heitor Mascarenhas Inglês (1884-1973)7, requisitado pelo Ministério das Colônias para ali desempenhar uma 'comissão extraordinária' de serviço como adido (Figura 2). Seu pai, Leovigildo Mascarenhas Inglês (18591912), oficial superior do exército colonial português há muito deslocado e estabelecido em Timor, falecera ali em combate no ano anterior, durante a guerra de Manufahi. Detentor de um confortável patrimônio, o major Leovigildo tinha interesses no petróleo, sendo titular de registros em Rai Noco, no reino de Suai, Comando Militar ${ }^{8}$ de Bobonaro (Castel Branco, 1915, p. 191), tendo mandado comprar, na Inglaterra, em 1908, equipamentos de perfuração, que seriam importados por meio de Darwin, na Austrália. Porém, com a sua morte prematura, o empreendimento dissolveu-se, desconhecendo-se se tais equipamentos terão efetivamente chegado a Timor?.

Passados alguns meses na Repartição Militar de Díli, Mascarenhas Inglês foi nomeado chefe dos Serviços de Agrimensura e Minas ${ }^{10}$ (Ministério das Colônias, 1914), tendo feito parte do grupo que, juntamente com oficiais holandeses, procedeu ao levantamento topográfico da região de fronteira para execução da sentença arbitral do juiz Charles E. Lardy (tratado de $1^{\circ}$. de outubro de 1904). Durante os dois anos que se seguiram, nos quais manteve essa atividade (19141915), foi reunindo uma série de amostras geológicas colhidas em diversos pontos do território, no sentido de propiciar uma ampla representação das principais formações da metade portuguesa da ilha.

Não é linear a compreensão das motivações do oficial, que não tinha certamente uma formação especializada nesta área do conhecimento, embora pese o fato de, no currículo acadêmico dos engenheiros militares, constarem matérias como História Natural, Mineralogia, Artes de Minas e Metalurgia. Dadas as funções que lhe estavam cometidas e a inexistência de serviços oficiais de geologia em Timor, estas coletas podem ser interpretadas como uma possível resposta às referidas recomendações do general Castel Branco e às solicitações com que seria confrontado no desempenho das suas funções no serviço de agrimensura e minas. No entanto, é igualmente plausível a hipótese de que os interesses do seu falecido pai no negócio do petróleo possam ter sido motivo bastante para lhe despertar a curiosidade pelo conhecimento da geologia da ilha, agindo, assim, por sua livre iniciativa, a título particular.

Certamente entregue ao Ministério das Colônias quando o oficial regressou a Lisboa, a coleção foi oferecida, em outubro de 1917, ao Museu Mineralógico e Geológico, no qual se vinha formando, desde finais do século XIX, um núcleo de geologia colonial. Porém, só na década de 1930, no consulado do catedrático Alfredo

7 Graduado pela Escola do Exército, este oficial foi mobilizado para o Corpo Expedicionário Português (CEP), principal força militar que Portugal, durante a Primeira Guerra Mundial, enviou para França, tendo posteriormente sido colocado em Angola, onde se fixou de forma permanente. Ascendeu ao posto de Coronel.

8 Em 1908, na sequência do processo de consolidação das fronteiras, Portugal dividiu o território timorense em 15 comandos militares, encarregados também da administração civil, substituídos uma década mais tarde pelas primeiras circunscrições civis.

9 Informação pessoal de Joseph Inácio e D. Carolina Mascarenhas Inglês, familiares dos referidos oficiais.

10 Criados em todas as antigas províncias ultramarinas portuguesas, os serviços de agrimensura tinham atribuídas competências muito variadas, designadamente na área da geodésia, de cadastro agrícola, dos recursos minerais e, de uma forma geral, de execução de todos os trabalhos de topografia, corografia e hidrologia.

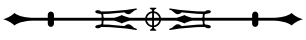




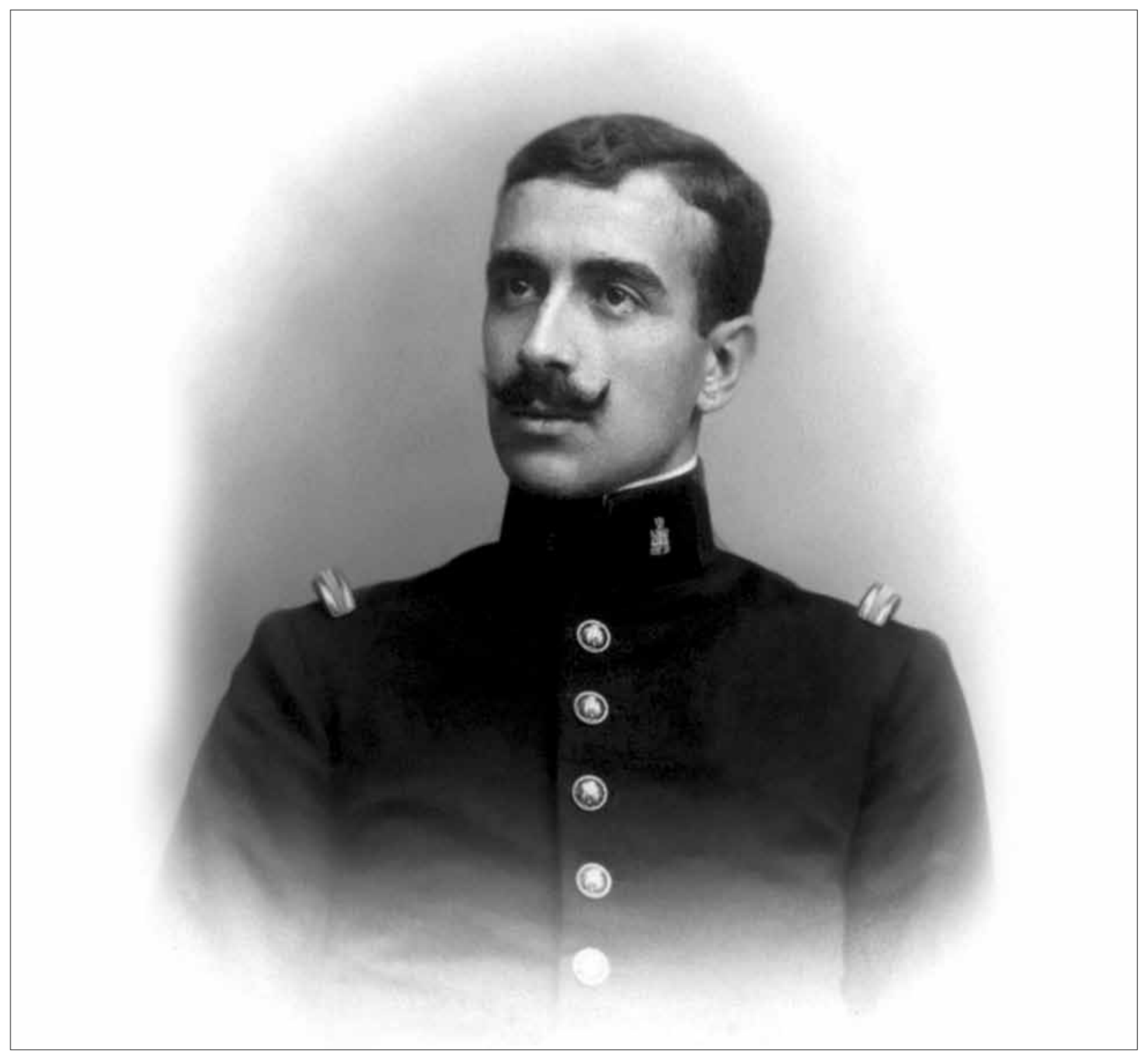

Figura 2. Heitor Mascarenhas Inglês, em meados de 1915. Cortesia do Arquivo Histórico Militar, n. P29A-II-L22-15012.

Machado e Costa (1870-1952), no âmbito da instalação da "Sala do Império Colonial Português"11, é que o naturalista António Sousa Torres (Figura 3) viria a ocuparse do estudo e da exposição desse acervo, dedicando-se principalmente à determinação dos fósseis e granjeando a colaboração do professor de Mineralogia Carlos Torre de Assunção (1901-1987) para a determinação de algumas rochas em lâmina delgada:

11 A "Sala do Império Colonial", onde foram concentradas as coleções mineralógicas dispersas pelos diversos segmentos do acervo do Museu Mineralógico e Geológico, é fruto da emergência de uma profunda 'cultura colonial', pautada, por um lado, pela nova orgânica do Ministério das Colônias (1929), saída do governo da ditadura militar, e, por outro, pelo Ato Colonial, lei centralizadora do regime, aprovada em julho de 1930, que definiu as formas de relacionamento entre a metrópole e os antigos territórios ultramarinos portugueses.

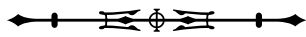




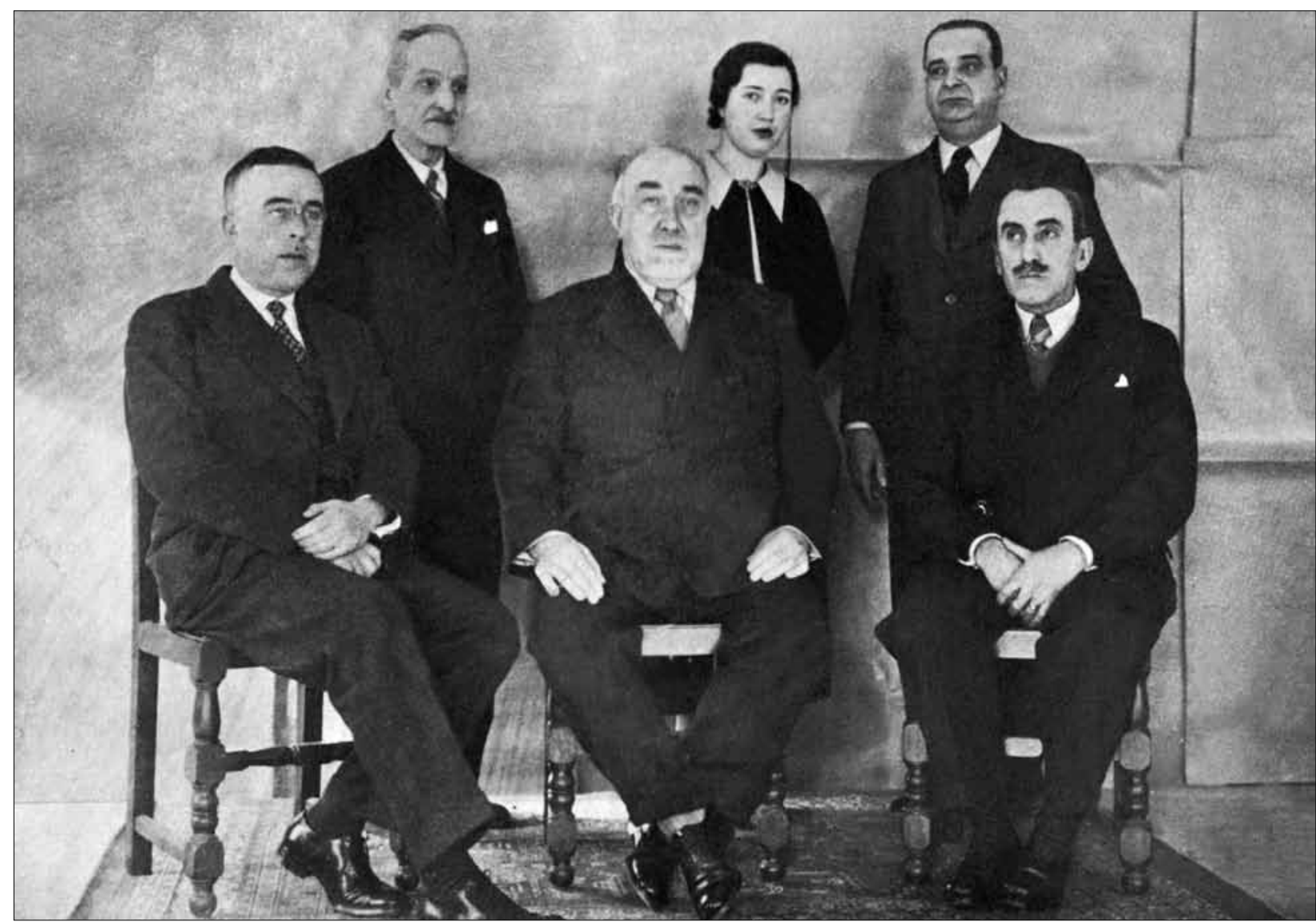

Figura 3. Corpo técnico do museu nos anos 1930. O diretor Alfredo Machado e Costa está sentado ao centro e Sousa Torres, à sua esquerda. Fonte: Costa (1938).

A coleção oferecida pelo major Mascarenhas Inglês, constituída por 83 amostras de Timor colhidas pessoalmente pelo oferente, representa, por certo depois da sua determinação recente pelo naturalista Sousa Torres, na metrópole, a única conhecida desta província, com valor geológico, enviada para museus portugueses (Costa, 1936, p. 73).

A coleção, que reunia cerca de oitenta exemplares, sobretudo rochas (Tabela 1), era essencialmente constituída por vários tipos de xistos e micaxistos, rochas vulcânicas, grés, calcários, alguns moluscos e braquiópodes fósseis (Figura 4), além de polipeiros recentes.

Na sua essência, pode-se considerar que essas coletas permitiam representar as duas grandes unidades geológicas estabelecidas pelos estudos pioneiros, respectivamente designadas por "montanhas xistosas" e "formação madrepórica" (Castro, 1867, p. 299), correspondentes, grosso modo, às formações paleozoicas e às sedimentares meso-cenozoicas, estas últimas caracterizadas pela abundância de calcários conchíferos e coralígenos. Este modelo foi sendo aperfeiçoado pelos estudos subsequentes, os quais vieram confirmar a ideia, que vinha quase desde o princípio do século, de que a estrutura geológica da ilha não era simples, distinguindo a existência de dois grandes complexos: um autóctone, essencialmente constituído por formações do Pérmico, Triásico, Jurássico e depósitos terciários e recentes, e um segundo, dito de carreamento ou de cobertura, constituído por uma série estratificada, cujos termos mais antigos são xistos clorito-sericíticos, filitos,

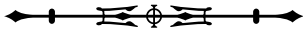


Tabela 1. Coleção Mascarenhas Inglês ${ }^{12}$. (*) Não foi possível estabelecer correspondência entre as localidades indicadas e as anotações do naturalista respeitantes às determinações.

(Continua)

\begin{tabular}{|c|c|c|c|}
\hline $\begin{array}{l}\text { Referência na } \\
\text { Figura } 5\end{array}$ & Procedência & $\begin{array}{l}\text { Número de } \\
\text { amostras }\end{array}$ & Determinações segundo António Sousa Torres \\
\hline 1 & Uai-Nete-Uai, Facumato & 1 & 'Cerezina' (ozocerite) \\
\hline 2 & $\begin{array}{l}\text { Comando Marítimo de Baucau } \\
\text { (Vila Salazar) }\end{array}$ & 1 & Pleurotomaria sp.; Turbo sp. \\
\hline 3 & $\begin{array}{l}\text { Comando Marítimo de } \\
\text { Oecusse }\end{array}$ & 15 & $\begin{array}{c}\text { Serpentina; lherzólito; peridotito; calcário biogênico } \\
\text { marmorizado; 'basaltito'; andesito augítico; } \\
\text { cloritoxisto; grauvaque }\end{array}$ \\
\hline 4 & Lautem, povoação & 1 & Arenito xistoso \\
\hline 5 & Comando Militar de Hatolea & 3 & $\begin{array}{l}\text { Calcite; enxofre nativo; micaxisto gneíssico; } \\
\text { calcário espatoide; pirite }\end{array}$ \\
\hline 6 & Lebos & 1 & Calcário fitogênico \\
\hline 7 & Boibau (Balibo?) & 1 & $(*)$ \\
\hline 8 & Nuno Pun & 3 & Calcário dolomítico \\
\hline 9 & Balibo & 3 & Venus sp.; Lithophyllum craspedium (Foslie) \\
\hline 10 & Comando Militar de Manatuto & 10 & $\begin{array}{l}\text { Spirifer sp.; calcedônia; serpentina; brecha vulcânica; } \\
\text { calcário dolomítico; polipeiros; cré branco }\end{array}$ \\
\hline 11 & Laclo & 1 & Pórfiro quartzífero; calcário gresoso; calcário \\
\hline 12 & Ataúro, praia & 2 & Polipeiros \\
\hline 13 & Soibada & 11 & $\begin{array}{l}\text { Calcário vidraço; calcário cristalino; } \\
\text { calcário sacaroide; pirite; calcite }\end{array}$ \\
\hline 14 & Be-Mutim & 8 & $\begin{array}{l}\text { Terebra sp.; Cypraea sp.; Arca sp.; } \\
\text { Spondylus sp.; Lima sp.; antozoário }\end{array}$ \\
\hline 15 & Fatumean & 2 & Calcário coralígeno \\
\hline 16 & Comando Militar de Bobonaro & 21 & $\begin{array}{l}\text { Quartzo-filádio; calcário com crinoides; arenito calcítico } \\
\text { limonite; quartzo leitoso; tefrito; tefrito nefelínico; } \\
\text { andesito augítico; arenito piritoso; arenito piritoso com } \\
\text { Arthrophycus sp.; calcário; brecha vulcânica; serpentina }\end{array}$ \\
\hline 17 & Encosta do Ramelau & 1 & Serpentina \\
\hline 18 & Suro & 1 & $(*)$ \\
\hline 19 & Suai (minas); Ermera & 2 & Calcário biogênico; Asaphus cf. tyrannus \\
\hline 20 & Betano & 1 & Polipeiro \\
\hline 21 & Praia norte de Timor, Metinaro & 5 & $(*)$ \\
\hline 22 & Entre Metinaro e Hera & 1 & $(*)$ \\
\hline 23 & Berenis, Cacotum & 5 & Porfirite micácea; serpentina; limonite (ocre amarelo) \\
\hline
\end{tabular}

12 Tanto quanto possível, procurou-se atualizar a designação das localidades referidas, tarefa apoiada pela Embaixada de Timor Leste em Lisboa. Contudo, não foi possível encontrar correspondência para algumas das indicações, pelo que, nesses casos, foi mantida a designação original. Quanto às determinações, dada a perda de grande parte dos exemplares, não foi possível confirmar a sua conformidade.

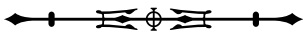


Tabela 1.

(Conclusão)

\begin{tabular}{c|c|c|c}
\hline $\begin{array}{c}\text { Referência na } \\
\text { Figura 5 }\end{array}$ & Procedência & $\begin{array}{c}\text { Número de } \\
\text { amostras }\end{array}$ & Determinações segundo António Sousa Torres \\
\hline 24 & Díli & 3 & Cloritoxisto; micaxisto tegular; talcoxisto \\
\hline 25 & Comando Militar de Viqueque & 3 & $(*)$ \\
\hline 26 & Mota-ar & 1 & Talcoxisto; grauvaque xistoso; xisto \\
\hline
\end{tabular}

anfibolitos e serpentinas ante-pérmicos, e calcários cretácicos e do terciário antigo (Gageonnet e Lemoine, 1957, 1958; Grunau, 1957, p. 730).

Convicto do ineditismo destes materiais, Sousa Torres não se coibiu de chamar a atenção das entidades oficiais para o interesse da coleção que acabara de determinar, endossando um convite ao coronel Álvaro Fontoura (1891-1975), antes do seu embarque para Timor, onde viria a desempenhar o cargo de governador, para ir ao museu ver uma coleção "geo-mineralógica"13 daquela ilha, única na metrópole: "há meses consagrei-me a estudá-la também micrograficamente assim garantindo uma boa utilidade aos interessados no conhecimento geológico do nosso Ultramar"14. $\mathrm{O}$ alento para este trabalho, confessava, remontava já a 1931, aquando da sua estada na França como bolsista da Junta de Educação Nacional, onde ouvira incentivos à "propaganda de estudos geológicos por gente portuguesa sobre a região Este de Timor, assim nos pertencendo a vez de imitarmos o exemplo germano-holandês"15.

O fato de a listagem original de Mascarenhas Inglês ser parca de elementos e de não lhe ser certamente fácil a visualização da distribuição geográfica das amostras deve ter levado Sousa Torres a tentar contactar o coletor, a quem dirigiu cópias da determinação realizada com o pedido de verificação: "Esta coleção fica (...) na sala do Império Colonial de cujo arranjo me ocupo presentemente (...). Se houver alguma coisa para emendar agradeço" ${ }^{\prime \prime}$.

Os documentos consultados não contêm elementos que permitam supor uma efetiva troca de informações entre os dois homens na sequência daquele pedido, pelo que é lícito admitir que a almejada resposta de Mascarenhas Inglês, radicado em Angola, só tenha chegado cerca de cinco anos depois. Acompanhava-a um "vegetaloide" (sic) com a indicação de cerca de uma vintena de locais de coleta, marcados sobre um esboço geológico incompleto da parte portuguesa da ilha, datado de Lisboa, 10 de maio de 194217, presumivelmente resultante da consulta dos levantamentos geológicos existentes à data, a que o autor teria tido acesso, nomeadamente os de Saint Clair, de que manda um apontamento a Sousa Torres ${ }^{18}$, e o de Wittouck, que, a julgar pelas notas do naturalista, este já conhecia.

13 Expressão simplista usada de forma recorrente pelo naturalista Sousa Torres ao referir-se às coleções de Timor, abreviando os termos 'geológica' e 'mineralógica'.

${ }^{14}$ Carta ao Engenheiro Alvaro Fontoura convidando-o a visitar o museu, 28 jul. 1937. Acervo Sousa Torres, AH-MUHNAC, Lisboa, Portugal. ST92.156.

15 Carta ao Engenheiro Álvaro Fontoura convidando-o a visitar o museu, 28 jul. 1937. Acervo Sousa Torres, AH-MUHNAC, Lisboa, Portugal. ST92.156.

16 Carta a Mascarenhas Inglês enviando documentação sobre a coleção, 28 jun. 1937. Acervo Sousa Torres, AH-MUHNAC, Lisboa, Portugal. ST92.154.4.

17 Carta de Mascarenhas Inglês a Sousa Torres, enviando mapa com a localização das colheitas, 11 maio 1942. Acervo Sousa Torres, AHMUHNAC, Lisboa, Portugal. ST92.154.4; ST012.318. Sublinhe-se que esta carta foi enviada de Lisboa, na qual o militar diz estar muito ocupado e apenas de passagem para Tancos, onde estava colocado.

18 Embora Carlos Teixeira (1952) e Azeredo Leme (1968) afirmem que Saint Clair não publicou o relatório dos trabalhos realizados em Timor no início da década de 1920, entre os documentos de Sousa Torres há uma nota manuscrita, muito possivelmente por Heitor Mascarenhas Inglês, com uma coluna estratigráfica e uma legenda alargada com a descrição e cronologia das principais formações segundo o geólogo americano, o que sugere que o oficial teve acesso a uma cópia do referido trabalho.

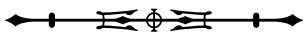




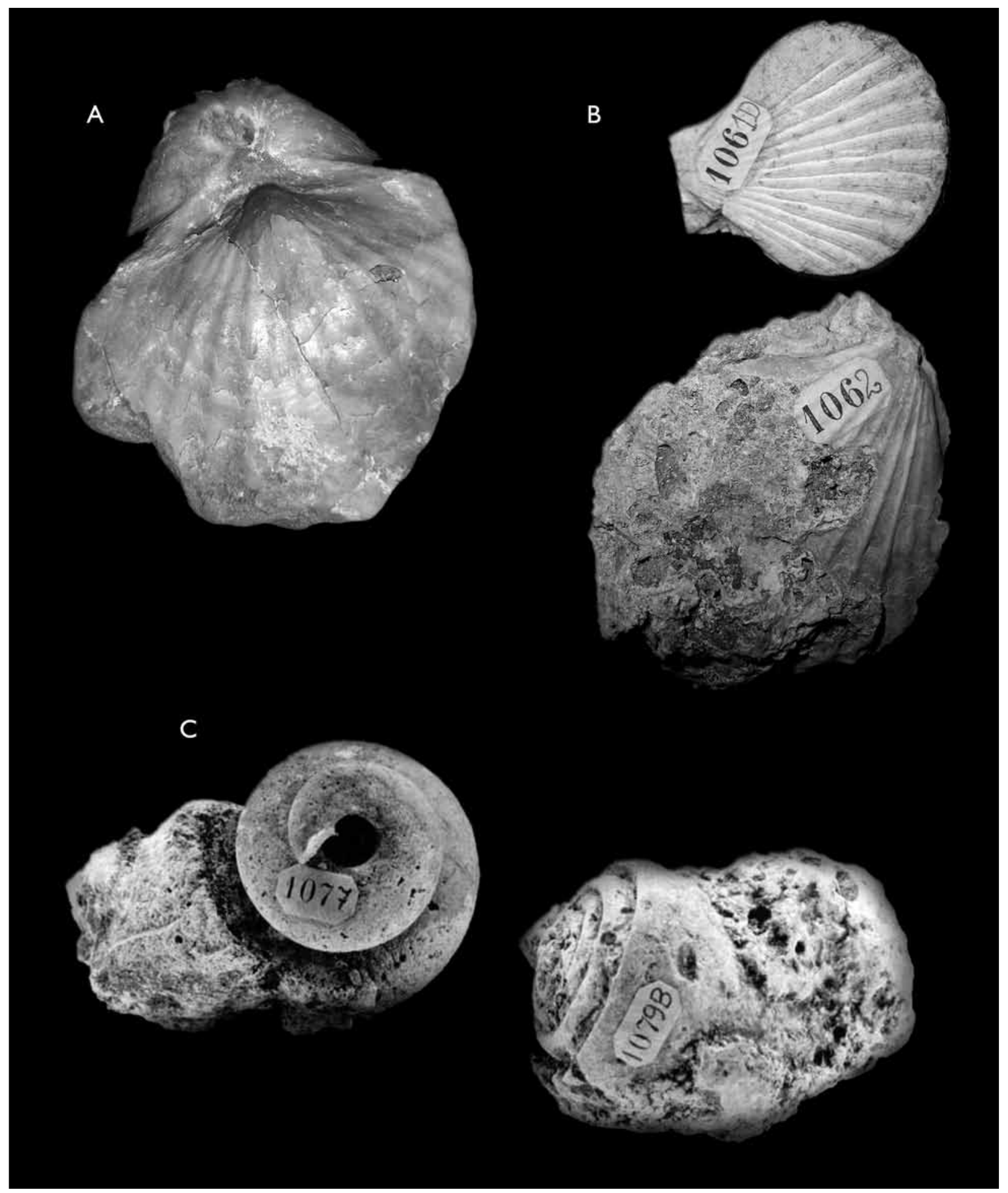

Figura 4. Fósseis da coleção Magalhães Inglês estudados por Sousa Torres. A) Spirifer sp.; B) Chlamys sp.; C) Calcário de crinoides. Fonte: Acervo do MUHNAC. 


\section{AS COLETAS DE ARTUR DO CANTO}

À coleção Mascarenhas Inglês viria juntar-se uma nova série de amostras de Timor, colhidas pelo engenheiro geógrafo Artur do Canto Resende (1897-1945), que, findas as comissões que desempenhara em Angola e Moçambique ao serviço das missões geodésicas, fora nomeado Adjunto da Missão Geográfica de Timor.

Embora o fulcro desta missão fosse o estabelecimento de uma rede geodésica para a elaboração de uma nova carta do território (Santos, 2011), era entendimento oficial - como, à época, afirmava o encarregado do governo, capitão Antônio Jacinto Magro - que os trabalhos relativos à identificação das zonas com potencial petrolífero constituíam "um dos capítulos do reconhecimento geológico que à Missão incumbe, julgo mesmo que de todos o mais importante" ${ }^{\prime 19}$. Assim, durante os trabalhos de campo em Aliambata, uma das regiões onde eram conhecidas várias ocorrências, Artur do Canto procedeu a uma "excelente recolha" de amostras, como reportaram mais tarde Torres e Soares (1952, p. 258). Encaminhadas para Lisboa muito antes da invasão japonesa da ilha, em fevereiro de 1942, estas rochas escaparam à destruição dos trabalhos da Missão Geográfica, que foi forçada a interromper as atividades durante a ocupação (Santos, 2011), sendo perdidos os seus elementos de trabalho, designadamente os duplicados dos levantamentos fotogramétricos conduzidos por Émile Brower e os elementos topográficos oferecidos por Ernest Keller no final dos levantamentos para a Companhia Ultramarina de Petróleos (Carvalho, 2003, p. 61-62).

Com as amostras, terá vindo "um único documento" elaborado pelo próprio engenheiro Canto, indicando, por curvas de nível, cotas e números, a localização e a classificação expedita das $\operatorname{coletas}^{20}$, o qual, segundo Sousa Torres, estava exposto na Sala do Império para apoio à interpretação da coleção ${ }^{21}$. Esse mapa pode ter se perdido juntamente com as amostras no incêndio de $1978^{22}$.

\section{INTERESSE REFORÇADO}

Aposentado em setembro de 1946, o interesse do naturalista pela geologia das províncias ultramarinas reforçou-se institucionalmente com a sua nomeação como 'assistente extraordinário' da Junta das Missões Geográficas e de Investigações Coloniais.

O espírito de 'cientista colonial', forjado com uma comissão civil de serviço em Angola (1922-1926), chefiando a Missão Geológica criada em 1921 (Brandão, 2008), consolidado por anos de trabalho com as coleções ultramarinas do museu, aliado à conjuntura política do momento, foram, seguramente, motivos suficientes para Sousa Torres retomar o trabalho com a coleção Mascarenhas Inglês. Timor, devastada pelos anos de ocupação e guerra, estava na ordem do dia, com o esforço de reconstrução em que o país se empenhava, confiado ao novo governador, capitão Óscar Ruas (1899-196-?), um conhecedor do território onde, pelos finais dos anos 1920, tinha desempenhado funções como comandante militar de Viqueque e de Oecusse e como diretor do Fomento:

É desejo do Governo que em Timor se não faça a simples reconstituição do que existia antes da ocupação japonesa: aproveitar-se-á este ensejo excepcional para, na medida do possível, fazer melhor e maior, utilizando a nossa experiência, os recursos do Tesouro, e os processos da técnica, de modo a erguer nos confins do Oriente uma colônia

19 Relatório do capitão de engenharia António Jacinto Magro, 25 out. 1939. Arquivo Histórico Ultramarino, Lisboa, caixa 1667.

${ }^{20}$ Carta a Carlos Teixeira, informando sobre a coleção Artur do Canto, 1 out. 1949. Acervo Sousa Torres, AH-MUHNAC, Lisboa, Portugal. ST92.160.

${ }^{21}$ Não foram encontrados elementos capazes de demostrar, de forma inequívoca, que Sousa Torres tenha estudado estas amostras, a que apenas se refere, de modo fugaz, na comunicação enviada ao congresso de Londres de 1948, e numa carta enviada ao governador da antiga província de Timor.

22 Desconhece-se se o coletor teria mais alguma documentação sobre a coleção, com intenção de trazê-la no regresso a Lisboa, o que não aconteceu, pois, durante a ocupação japonesa, tornou-se um lutador e resistente, falecendo na prisão dos invasores em fevereiro de 1945.

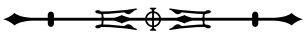


modelar, ou, pelo menos, bem demonstrativa da nossa capacidade de ação (...) Timor tem estado sempre nas preocupações e nos cuidados do Governo e há-de reerguer-se com mais brilho e pujança da prostração em que jazeu durante anos e oprobriosa ocupação estrangeira (Caetano, 1946, p. 4-5).

Pouco tempo depois, anunciava-se para Londres, em agosto de 1948, a realização da $18^{\mathrm{a}}$ sessão do Congresso Internacional de Geologia, o maior fórum internacional desta área do saber, que se encontrava suspenso desde os anos antes da deflagração da Segunda Guerra Mundial. Era uma oportunidade imperdível para mostrar ao mundo o esforço de reconstrução de Timor e o estado da arte da geologia colonial portuguesa.

Se a conjuntura proporcionou o motivo, o mote foi a nomeação de Ruy Cinatti Monteiro Gomes (1915-1986) para chefe de gabinete do governador. Sousa Torres e Cinatti eram primos e o relacionamento que mantinham permitiu ao naturalista pedir o envio de novos materiais daquela província ultramarina, tendo em vista a preparação de uma nota científica, esgotada que estava a amostragem do museu:

Já me inscrevi na "membership" do International Geological Congress para Londres em 1948, prometendo a seguinte comunicação "New geological contibutions on Portuguese Timor" (...) $\bigcirc$ meu trabalho tem incidido sobre os materiais que tenho em meu poder; mas se, a não longa tardança, eu receber amostras geológicas por ti obtidas, com assentimento do teu ilustre Governador, delas tirarei resultados de exame científico, também frisando a sua procedência e os nomes de quem facultar esses motivos de interesse nacional ${ }^{23}$.

O pedido viria a ser reforçado na troca de cumprimentos de ano novo, em que o naturalista lhe refere a intenção de pretender preparar "uma substanciosa notícia (...) com motivo num certo número de amostras geológicas a mim endereçadas, mas figurando depois nos documentários coloniais de escolas superiores portuguesas"24. Por estas linhas se depreende que a amostragem seria remetida de Timor a título pessoal, e não institucional, uma vez que Sousa Torres estava aposentado e afastado do museu, e que, depois de estudada, o naturalista planejava reparti-la pelas instituições científicas que tinham acervos do ultramar: além do Museu Mineralógico, certamente os Serviços Geológicos de Portugal, onde, no início do século, se tinha constituído um Museu de Geologia Colonial (Brandão, 2010); a Sociedade de Geografia, da qual era sócio de longa data, herdeira do primeiro museu colonial constituído em Portugal; e também, talvez, a Universidade de Coimbra, onde se ensaiava a formação de uma "Galeria de Paleontologia Colonial" (Callapez et al. , 2008).

Nos últimos meses de 1947, Cinatti percorreu a antiga província ultramarina a fim de elaborar um levantamento fitogeográfico, com o qual viria a concluir, em Lisboa, a sua licenciatura em Agronomia. As expedições botânicas teriam sido também aproveitadas para a coleta das amostras geológicas que fez chegar às mãos do naturalista (Tabela 2) ${ }^{25}$.

Sousa Torres e José Manso Pires Soares (1901-1977), colaborador da Junta das Missões Geográficas, com quem o naturalista passara a partilhar o estudo das coleções coloniais, tinham já em fase avançada de preparação o trabalho para o congresso de Londres. No entanto, essas amostras ainda teriam sido observadas, como se retira do agradecimento com que encerra a comunicação enviada à magna reunião e dos apontamentos do naturalista.

Outros materiais, talvez ainda colhidos por Cinatti, remetidos por via oficial, chegaram já tarde para que o seu

${ }^{23}$ Carta a Ruy Cinatti, solicitando amostras de Timor, 1 nov. 1947. Acervo Sousa Torres, AH-MUHNAC, Lisboa, Portugal. ST92.69.

${ }^{24}$ Carta a Ruy Cinatti, retribuindo votos de Boas Festas, 7 nov. 1947. Acervo Sousa Torres, AH-MUHNAC, Lisboa, Portugal. ST92.165.

25 Cinatti, com doutorado em Antropologia por Oxford, voltaria a oferecer à Faculdade de Ciências amostras recolhidas nos anos 1950 durante a expedição antropológica realizada com Mendes Correia (1888-1960), lente da Universidade do Porto, as quais foram estudadas e publicadas por Torre de Assunção e pelo naturalista José Brack-Lamy.

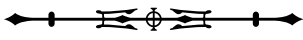


Tabela 2. Coleção Ruy Cinatti.

\begin{tabular}{|c|c|c|}
\hline $\begin{array}{l}\text { Referência na } \\
\quad \text { Figura } 5\end{array}$ & Procedência & Determinações segundo António Sousa Torres \\
\hline 27 & Junto a Fohorem & Serpentina \\
\hline \multirow[t]{2}{*}{28} & Entre Subão e Manatuto, junto ao mar & Diorito \\
\hline & Numa ribeira próxima de Díli & Paragnaisse \\
\hline 29 & A 18 km NNE de Uatu-Lari, Vai-Na-Nu & Calcário biogênico \\
\hline 30 & A $2 \mathrm{~km}$ de Vemasse & Calcário poligênico com briozoários \\
\hline \multirow[t]{2}{*}{31} & Lospalos, próximo de Pè-Palai & Calcário cristalino metamórfico \\
\hline & Uatu-Lari, Uè-Bùi & Sienito \\
\hline 32 & Hera & Anfibolito \\
\hline \multirow[t]{2}{*}{33} & Ermera & Xisto ardosífero \\
\hline & Junto ao vulcão de Uè-Silo & Calcário; calcário de Fissurinas \\
\hline 34 & Tutuala & Calcário margoso \\
\hline \multirow[t]{2}{*}{35} & Mota Coa & Sienito \\
\hline & A 24 km W de Manatuto & $\begin{array}{l}\text { Rocha de contato entre micaxisto } \\
\text { gneíssico e calcário }\end{array}$ \\
\hline \multirow[t]{4}{*}{36} & Letefoho & Tufo vulcânico \\
\hline & A 23 km W de Manatuto, na estrada de Díli & Peridotito \\
\hline & Bobonaro & Serpentina \\
\hline & Luca-Tòi & Cherte \\
\hline 37 & Entre Viqueque e Uatu-Lari & Calcário silicioso \\
\hline \multirow[t]{2}{*}{38} & $\begin{array}{l}\text { Mundo Perdido, no sopé, } \\
\text { junto à estrada Ossu-Venilale }\end{array}$ & Calcário? \\
\hline & A 5 km W de Manatuto, na estrada de Díli & Calcário cristalino \\
\hline 39 & Lòi-Una, Mota-Coa & Brecha quartzosa \\
\hline 40 & Baucau, Vila Nova (Campo de aviação, Vila Salazar) & Calcário biogênico com foraminíferos \\
\hline
\end{tabular}

estudo fosse considerado na nota enviada ao congresso, esboçando a sucessão estratigráfica da ilha, que, "com [apenas] cerca de 200 palavras [teve] o cuidado de bem acentuar quais eram os inéditos fatos de Ciência a que reportavam"26. Porém, o cientista desvalorizou a situação, dizendo que "não obstante essa contrariedade, posso garantir que a definitiva notícia geo-mineralógica será elaborada, sobre os resultados de estudo do material remetido por $V$. Ex. ${ }^{a}$ e do qual espero haver durante o mês de Janeiro p. f. ultimado o primeiro reconhecimento" 27 .

\section{ÚLTIMAS AMOSTRAS}

Na senda das coletas de Cinatti e ciente do interesse que trariam para a consolidação do reconhecimento geológico

${ }^{26}$ Informação sobre a atividade colonial de António Sousa Torres, 17 jan. 1949. Acervo Sousa Torres, AH-MUHNAC, Lisboa, Portugal. ST92.319.

${ }^{27}$ Carta ao governador da Província de Timor, acusando a recepção de amostras, 15 nov. 1948. Acervo Sousa Torres, AH-MUHNAC, Lisboa, Portugal. ST92.158.4.

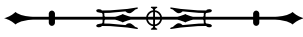




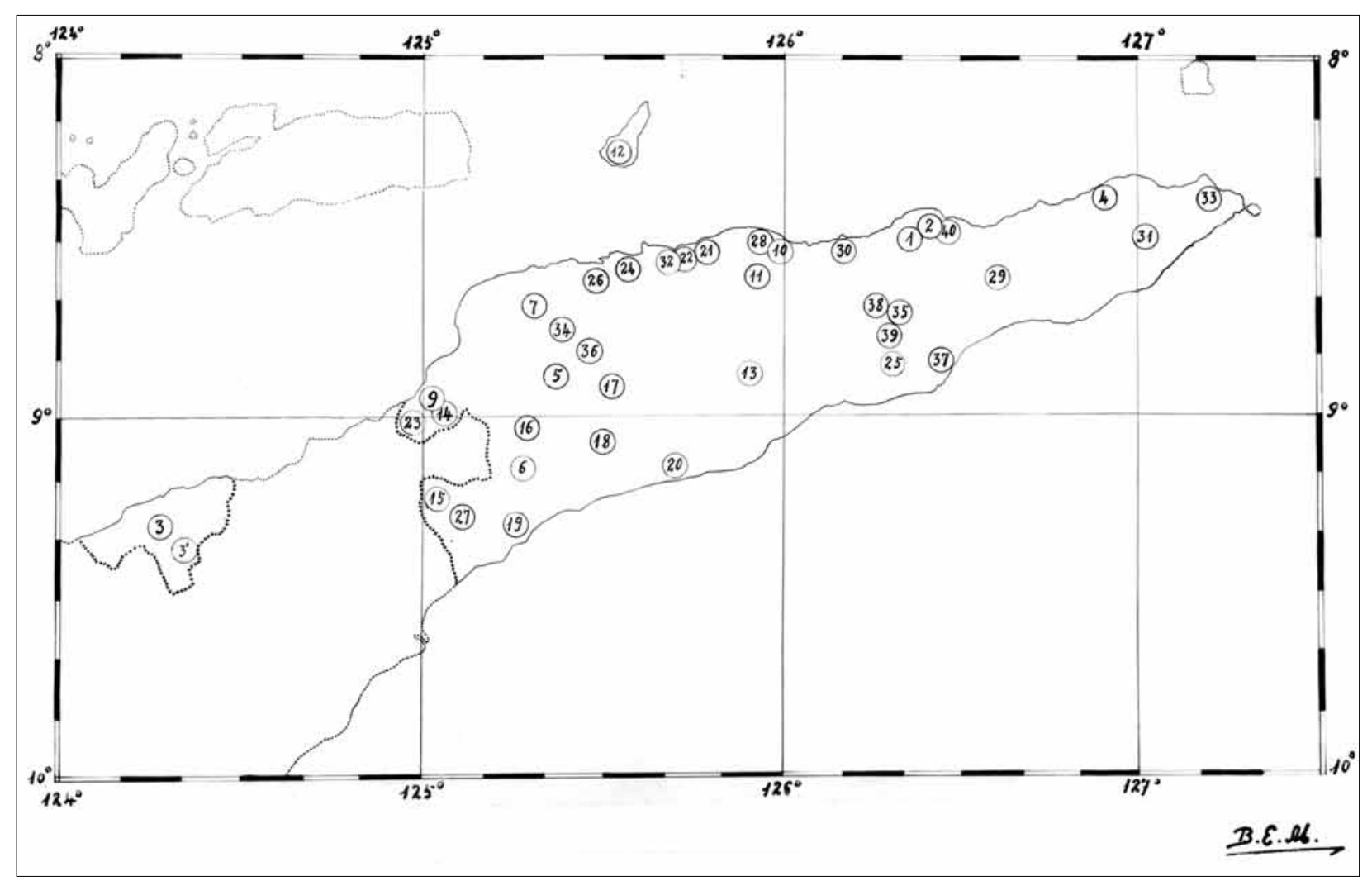

Figura 5. Mapa de Sousa Torres com a localização das coletas de Mascarenhas Inglês (1 a 26) e Ruy Cinatti (27 a 40), listadas nas Tabelas 1 e 2, preparado para a apresentação de Londres. Espólio científico de António Sousa Torres. Fonte: Acervo do MUHNAC.

global da província, Óscar Ruas expediu às circunscrições civis timorenses, em julho de 1949, uma ordem para que nestas se procedesse à coleta e ao envio para a sede do governo em Díli de amostras geológicas das respectivas regiões. Desta forma, reuniu, com sucesso, um mostruário de várias dezenas de peças remetidas ao Ministério das Colônias, em Lisboa, com o pedido de que fosse entregue a Sousa Torres.

Assim, entre 1949 e 1952, chegaram às mãos de Sousa Torres cerca de duas centenas de exemplares provenientes das regiões de Bobonaro, Díli, Baucau, Manatuto e Lautém, na costa norte; de Cova Lima e Viqueque, na costa sul; de Ermera, no interior montanhoso; e do enclave de Oecussi.
Salvo alguns poucos exemplares de pirolusite, malaquite e gesso, todos os restantes exemplares são rochas ${ }^{28}$, a maioria com pequenas dimensões.

Concluído está o meu exame preliminar de toda a coleção de minerais e de rochas, que $\mathrm{V}$. Ex. ${ }^{\mathrm{a}}$ houve por bem consignar ao meu estudo sistemático (...) Praticamente incólumes chegaram cá os dois grandes caixotes, mas igual sorte não teve o seu conteúdo, pois a embalagem da maior parte das amostras não resistiu à violência das baldeações de carga, nos navios que trouxeram esse material. As etiquetas de cada exemplar na sua maioria chegaram dispersas e não aproveitáveis. Posso porém remediar tão molesto prejuízo, desde que eu receba uma outra coleção, formada por fragmentos de minerais e de rochas, colhidos precisamente

\footnotetext{
${ }^{28}$ Recorde-se que estas amostras estavam na posse da família de Sousa Torres, que as ofereceu ao museu, onde ficaram identificadas como "Coleção Sousa Torres (Timor)". Deve-se registrar, neste lote, a completa ausência de fósseis; ou não foram recolhidos, ou o naturalista tê-los-á apartado e dado outro destino, que se desconhece.
}

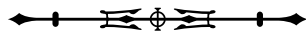




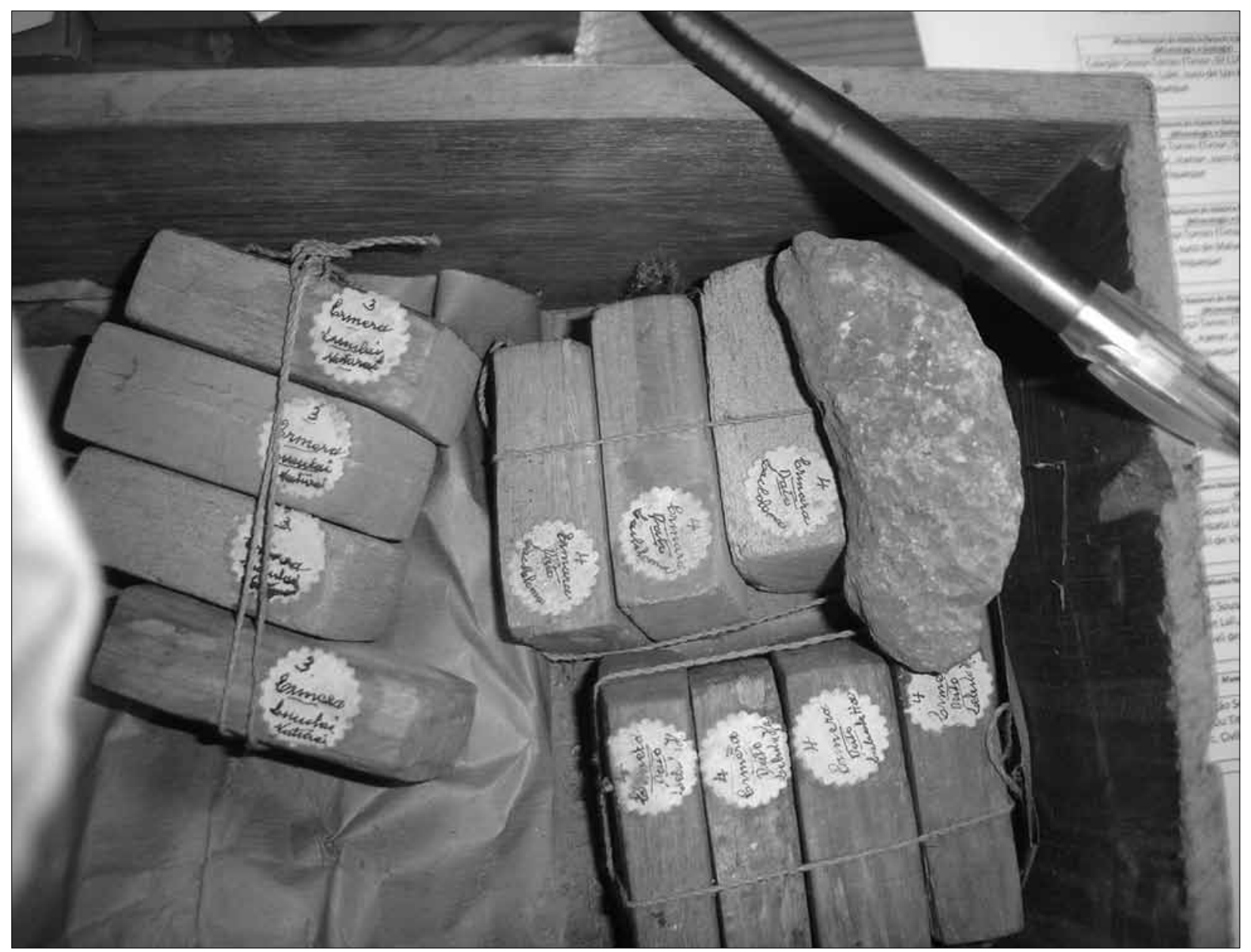

Figura 6. Algumas amostras das coletas promovidas pelo governo provincial em 1949. Fonte: Acervo do MUHNAC.

nos mesmos locais onde foram obtidas as amostras que estão em meu poder (...) De tal maneira farei retomar a sua real valia à coleção $(. .$.$) porque$ representa alto préstimo à causa da investigação científica portuguesa no nosso Ultramar².

A marcação e o talhe destas amostras (Figura 6), entretanto incorporadas no acervo do MUHNAC, pressupõem a interiorização do apelo de Sousa Torres, bem como a existência, desde então, de um cuidadoso trabalho de preparação, certamente produzido pelo pessoal adstrito às missões científicas de Timor.

\section{NOTAS FINAIS}

O estudo das coleções de rochas e fósseis de Timor, confiadas ao museu até finais dos anos 1940, permitiu alcançar duas grandes ordens de objetivos: no plano científico, apresentavam-se ao mundo, no mais importante fórum da especialidade (o Congresso Geológico Internacional), os avanços da ciência colonial portuguesa e o trabalho de investigação que, neste âmbito, se fazia na Faculdade de Ciências de Lisboa e, em particular, no seu museu Mineralógico e Geológico; no plano político,

${ }^{29}$ Carta ao governador da Província de Timor sobre amostras recebidas, 22 fev. 1949. Acervo Sousa Torres, AH-MUHNAC, Lisboa, Portugal. ST92.158.5.

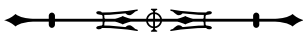


- Estado, por meio da Universidade, proporcionava à pública fruição estas coleções que, expostas na Sala Colonial do museu, sublinhavam a unidade do Império, consagrada nas principais diretivas da política ultramarina portuguesa, mostrando a todos que o país soberano estava atento às necessidades da colonização, procedendo ao reconhecimento científico dos territórios sob sua administração, vetor fundamental das políticas de fomento.

No que diz respeito às coleções posteriores àquela data, não foram encontrados elementos que demonstrem, sem margem para dúvidas, ter sido efetivamente estudadas, o que poderá dever-se, em parte, à dificuldade que o naturalista certamente encontrou na obtenção de lâminas delgadas, limitação decorrente do tamanho das amostras ou do seu afastamento da vida do museu. Pesem, embora, as suas limitações, no que diz respeito aos contextos geológicos, que comprometem o valor científico da amostragem, este acervo - ainda inédito - testemunha uma tentativa de contribuição oficial para um amplo conhecimento da geologia da mais longínqua parcela do Império Português no Oriente, sendo, por isso, uma peça fundamental para o estudo e a divulgação da história da geologia em Portugal.

\section{AGRADECIMENTOS}

O autor agradece aos colegas César Lopes e Liliana Póvoas (MUHNAC) as facilidades concedidas na consulta do espólio científico de António Sousa Torres; aos familiares do Coronel Mascarenhas Inglês, Sr. Joseph Inácio e D. Carolina Mascarenhas Inglês, os documentos fotográficos e as informações fornecidas; à Professora Fátima Nunes (Universidade de Évora) os comentários que muito contribuíram para a clareza do texto; ao Sr. José Amaral, adido cultural da Embaixada de Timor Leste em Lisboa, a revisão das localidades referidas.

\section{REFERÊNCIAS}

AUDLEY-CHARLES, Michael. Geology of Portuguese Timor. Geological Society, Memoirs, Londres, v. 4, p. 4-84, 1968.
BRANDÃO, José. Bacharel António Sousa Torres (1876-1958): contributos de um "naturalista-geológo" para a organização dos acervos geológicos das Faculdades de Ciências do Porto e Lisboa. In: CONGRESSO LUSO-BRASILEIRO DE HISTÓRIA DAS CIÊNCIAS, 1., 2011, Coimbra. Resumos... Coimbra: Imprensa da Universidade de Coimbra, 2011. p. 1136-1151.

BRANDÃO, José. $\bigcirc$ acervo colonial das "Comissões Geológicas" de Portugal (1857-1918). Nota preliminar. In: BRANDÃO, José; CALLAPEZ, Pedro; MATEUS, Octávio; CASTRO, Paulo (Eds.). Colecções e museus de Geologia: missão e gestão. Lisboa: Universidade de Coimbra, 2010. p. 113-120.

BRANDÃO, José. Missão Geológica de Angola: contextos e emergência. Memórias e Notícias, Nova Série, n. 3, p. 285292, 2008.

CAETANO, Marcelo. Acto de posse do novo Governador de Timor. Discurso de S. Ex. ${ }^{a}$ o Ministro das Colónias. Boletim Geral das Colónias, v. 22, n. 253, p. 3-6, 1946.

CALLAPEZ, Pedro; MARQUES, Júlio; MATIAS, Carlos. Os estudos de paleontologia ultramarina na Universidade de Coimbra e os fósseis do litoral de Benguela, Angola. Memórias e Notícias, Nova Série, n. 3, p. 301-308, 2008.

CARVALHO, Manuel Ferreira de. Relatório dos Acontecimentos de Timor (1942-45). Reedição do relatório publicado em 1947. Lisboa: Edições Cosmos/Instituto da Defesa Nacional, 2003.

CASTEL BRANCO, José. Província de Timor: informações relativas aos jazigos de petróleo e à agricultura. Lisboa: Ministério das Colônias, 1915.

CASTRO, Affonso. As possessões portuguesas da Oceania. Lisboa: Imprensa Nacional, 1867.

COSTA, Machado e. O Museu Mineralógico e Geológico. Revista da Faculdade de Ciências, v. 1, n. 3, p. 124-175, 1938.

COSTA, Machado e. $\bigcirc$ Museu Colonial. Boletim do Museu e Laboratório Mineralógico e Geológico da Universidade de Lisboa, Segunda Série, n. 5, p. 69-80, 1936.

DIRECÇÃO-GERAL DO ULTRAMAR. Projecto de organização administrativa do districto autonomo de Timor elaborado no districto em 1906. Lisboa: Imprensa Nacional, 1906.

DUARTE, Teófilo. Timor: ante-câmara do inferno!? Famalicão: Tipografia Minerva, 1930.

GAGEONNET, Robert; LEMOINE, Marcel. Contribution à la connaissance de la Géologie de la Province Portugaise de Timor. Lisboa: Junta de Investigações do Ultramar, 1958. (Estudos, Ensaios e Documentos, n. 48).

GAGEONNET, Robert; LEMOINE, Marcel. Note préliminaire sur la géologie du Timor Portugais. Garcia de Orta, Lisboa, v. 5, n. 1, p. 153-163, 1957. 
GRUNAU, Hans. Geologia da parte oriental do Timor Português: nota abreviada. Garcia de Orta, Lisboa, v. 5, n. 4, p. 727-737, 1957.

LEME, Azeredo. Breve ensaio sobre a Geologia da Província de Timor. Lisboa: Junta de Investigações do Ultramar, 1968.

LENCASTRE, Júlio. Exposição de Timor. Lisboa: Museu Colonial/ Sociedade de Geografia de Lisboa, 1931.

MINISTÉRIO DAS COLÔNIAS. 3. ${ }^{\text {a }}$ Repartição. Boletim Oficial do Governo da Província de Timor, XV ano, n. 7, 14 fev. 1914.

RIBEIRO, António; LEME, Azeredo. Geologia de Timor. In: COTELO NEIVA, José; RIBEIRO, António; VITOR, Mendes; NORONHA, Fernando; RAMALHO, Magalhães (Eds.). Ciências geológicas: ensino, investigação e sua história. Lisboa: Associação Portuguesa de Geólogos, 2010. v. 3, p. 279-283.

SANTOS, Paula. A Missão Geográfica de Timor. In: COLÓQUIO TIMOR: MISSÕES CIENTÍFICASE ANTROPOLOGIA COLONIAL, 1., 2011, Lisboa. Atas... Lisboa: Arquivo Histórico Ultramarino, 2011. 1 CD-ROM. p. 1-20.
TEIXEIRA, Carlos. Notas sobre a geologia e a tectónica de Timor. Estudos Coloniais: Revista da Escola Superior Colonial, Lisboa, v. 3, p. 85-154, 1952.

TORRES, A. Sousa; SOARES, Pires. Quelques contributions géologiques sur le Timor Portugais. In: INTERNATIONAL GEOLOGICAL CONGRESS, 18., 1952, Londres. Memória... Londres: Geological Society of London, 1952. p. 238-239.

VAQUINHAS, Santos. Productos de Timor. Boletim da Sociedade de Geografia de Lisboa, Segunda Série, p. 41-45, 1882a.

VAQUINHAS, Santos. Carta ao Secretário da Sociedade de Geografia Sr. Luciano Cordeiro, Dili, 11 de Abril de 1882. Boletim da Sociedade de Geografia de Lisboa, Segunda Série, p. 242, 1882 b.

WANNER, Johann (Ed.). Paläontologie von Timor: nebst kleineren Beiträgen zur Paläontologie einiger anderer Inseln des ostindischen Archipels. Stuttgart: Schweizerbart, 1914-1929. 16 v.

WITTOUCK, Serge V. (Ed.). Exploration of Portuguese Timor. Report of Allied Mining Corporation to Asia Investment Company, Ltd. Batavia: Asia Investment Company, 1937. 